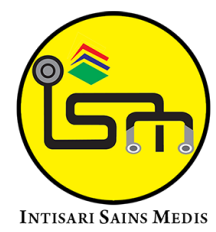

Published by Intisari Sains Medis

\section{Peran terapi mesenchymal stem cell (MSC) dalam penatalaksanaan luka bakar: sebuah tinjauan sistematis}

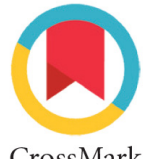

CrossMark
'Dokter Umum, Fakultas Kedokteran Universitas Hang Tuah, Surabaya, Indonesia
*Korespondensi penulis:

Zendio Abednego Santoso; Dokter Umum, Fakultas Kedokteran Universitas Hang Tuah, Surabaya, Indonesia;

zendioabe@gmail.com

\author{
Zendio Abednego Santoso ${ }^{{ }^{*}}$
}

\title{
ABSTRACT
}

Background: Burn cases are still a challenge and a burden in the health sector due to the morbidity and mortality it causes. The current management of burns has not produced satisfactory clinical outcomes in terms of wound healing. Mesenchymal stem cell (MSC) therapy is known to have an effective curative effect in healing burns. This systematic review aims to determine the role of MSCs in the management of burns.

Methods: A systematic literature review was carried out by searching the literature on Google Scholar, Pubmed and Cochrane Library, where the literature selection used PRISMA diagrams. The inclusion criteria used were studies in the form of clinical trials examining the role of MSCs in the management of thermal burns. The study was not a clinical trial, studies with research samples in the form of non-thermal burns, research subjects were not rats or mice, MSC was not used as the main intervention therapy, and did not involve the

control group in the study were excluded so that 12 studies that met the eligibility criteria were obtained. Results: 12 studies carried out the synthetic analysis in randomized clinical trials using research subjects in the form of mice and rats. The MSC therapy was isolated from bone marrow, cord blood and adipose tissue. MSC therapy plays a role in accelerating the healing process of burns through several biomolecular mechanisms such as reducing apoptosis, suppressing inflammatory responses and oxidative stress, triggering angiogenesis, accelerating re-epithelialization and tissue remodeling. MSC therapy has also been shown to minimize the formation of contractures and scar tissue,

Conclusion: The role of MSC therapy in burns is to accelerate the wound healing process, reduce the occurrence of contractures and scar tissue so that it is very potential to be applied in the management of burns.

\section{Keywords: burns, mesenchymal stem cell, a stem cell.}

Cite This Article: Santoso, Z.A. 2021. Peran terapi mesenchymal stem cell (MSC) dalam penatalaksanaan luka bakar: sebuah tinjauan sistematis. Intisari Sains Medis 12(3): 927-933. D0I: 10.15562/ism.v12i3.1167

\section{ABSTRAK}

Latar Belakang: Kasus luka bakar masih menjadi tantangan dan beban di bidang kesehatan akibat morbiditas dan mortalitas yang ditimbulkannya. Penatalaksanaan luka bakar saat ini belum mampu menghasilkan luaran klinis yang memuaskan dari segi penyembuhan luka. Terapi mesenchymal stem cell (MSC) diketahui memiliki efek kuratif yang efektif dalam proses penyembuhan luka bakar. Tujuan dari tinjauan pustaka sistematis ini adalah untuk mengetahui peranan MSC dalam penatalaksanaan luka bakar.

Metode: Tinjauan pustaka sistematis dilakukan dengan pencarian literatur pada Google Scholar, Pubmed, dan Cochrane Library dimana pemilihan literatur menggunakan diagram PRISMA. Kriteria inklusi yang digunakan adalah studi berupa uji klinis yang meneliti peran MSC dalam tatalaksana luka bakar termal. Studi bukan berupa uji klinis, studi dengan sampel penelitian berupa luka bakar non-termal, subjek penelitian bukan berupa tikus atau mencit, MSC tidak digunakan sebagai terapi intervensi utama, serta tidak melibatkan kelompok kontrol dalam studinya dilakukan eksklusi sehingga didapatkan 12 studi yang memenuhi kriteria eligibilitas.

Hasil: Terdapat 12 studi yang dilakukan analisis sintesis berupa uji klinis acak menggunakan subjek penelitian berupa mencit dan tikus. Terapi MSC yang digunakan diisolasi dari sumsum tulang belakang, darah tali pusat dan jaringan adiposa. Terapi MSC berperan mempercepat proses penyembuhan luka bakar melalui sejumlah mekanisme biomolekuler berupa 
mengurangi apoptosis, menekan respon inflamasi dan stress oksidatif, memicu angiogenesis, mempercepat re-epitelisasi, serta remodelling jaringan. Terapi MSC juga terbukti meminimalisir terbentuknya kontraktur dan jaringan parut,
Simpulan: Peran terapi MSC dalam luka bakar adalah mempercepat proses penyembuhan luka, mengurangi terjadinya kontraktur dan jaringan parut sehingga sangat potensial untuk diaplikasikan dalam tatalaksana luka bakar.

Kata Kunci: luka bakar, sel punca, sel punca mesenkimal.

Sitasi Artikel ini: Santoso, Z.A. 2021. Peran terapi mesenchymal stem cell (MSC) dalam penatalaksanaan luka bakar: sebuah tinjauan sistematis. Intisari Sains Medis 12(3): 927-933. D0I: 10.15562/ism.v12i3.1167

\section{LATAR BELAKANG}

Kasus luka bakar masih menjadi tantangan dan beban di bidang kesehatan akibat morbiditas dan mortalitas yang ditimbulkannya. Morbiditas akibat luka bakar juga sangat berpengaruh terhadap aktivitas fungsi sehari-hari yang menyebabkan ketergantungan dalam melakukan aktivitas hidup dan kehilangan pekerjaan hingga ketidakpastian masa depan. ${ }^{1,2}$ Berdasarkan data WHO, kasus mortalitas akibat luka bakar diperkirakan sekitar 265.000 jiwa setiap tahunnya. ${ }^{2}$ Dari studi epidemiologi di Rumah Sakit Cipto Mangunkusumo (RSCM) tahun 2011-2012 data pasien yang dirawat selama periode 2 tahun adalah 303 pasien dengan sebagian besar pasien dengan luka bakar berat sebanyak 45,87\%. Sedangkan data dari RSUP Sanglah Denpasar tahun 2012 dari total 154 pasien yang dirawat, sebanyak 13 orang meninggal $(8,42 \%)$ akibat ledakan api dengan luka bakar luas dan dalam. ${ }^{3}$

Luka bakar dapat menyebabkan komplikasi serius seperti dehidrasi, ketidakseimbangan elektrolit, infeksi, dan bahkan kematian. Saat ini penatalaksanaan luka bakar derajat berat meliputi resusitasi cairan, tindakan debridement, perawatan luka, kontrol infeksi, dan dukungan metabolik serta penatalaksanaan trauma inhalasi pada pasien dengan luka bakar inhalasi. ${ }^{1}$ Namun masih terdapat sejumlah tantangan dalam penatalaksanaan luka bakar seperti halnya proses penyembuhan yang rentan untuk terjadinya komplikasi seperti risiko infeksi, kehilangan darah, nyeri hebat, hingga timbulnya kontraktur. Pada pasien dengan luka bakar ekstensif dapat dilakukan skin graft, namun dibutuhkan waktu cukup lama untuk penyembuhan. Kelemahan dari skin graft adalah hasil akhir kosmetik yang kurang memuaskan dan berdampak pada psikologis pasien. Selain itu timbulnya jaringan parut dan kontraktur juga akan mempengaruhi fungsi pasien seperti terbatasnya ruang gerak sendi. ${ }^{2,4}$

Oleh karena itu dibutuhkan suatu inovasi dalam penatalaksanaan kasus luka bakar untuk menghasilkan waktu penyembuhan yang lebih cepat dan luaran klinis yang lebih memuaskan. Metode yang sedang diteliti saat ini adalah penggunaan sel punca atau stem cell. Salah satu jenis sel punca yang tengah dikembangkan secara luas adalah mesenchymal stem cell (MSC). ${ }^{5,6}$ Sejumlah studi melaporkan efek kuratif MSC dalam berbagai penyakit, termasuk pada luka bakar. Mesenchymal stem cell memiliki kemampuan dapat berdiferensiasi menjadi sel epidermal dan adneksa kulit dan dapat diisolasi dan diamplifikasi dari berbagai sumber dalam tubuh seperti tali pusat, sumsum tulang belakang, dan jaringan adiposa. Studi pada hewan coba menunjukkan potensi MSC secara efektif dapat mempercepat penyembuhan luka. MSC dilaporkan dapat mengurangi area luka bakar pada hewan coba berupa tikus dan mencit. ${ }^{7-9}$ Mesenchymal stem cell disebutkan dapat mengurangi apoptosis sel, mengurangi respon inflamasi dan stress oksidatif, menginduksi angiogenesis, mempercepat proses re-epitelisasi, dan remodelling jaringan. ${ }^{2}$ Saat ini belum terdapat suatu tinjauan sistematik dan komprehensif mengenai peranan MSC pada luka bakar. Oleh karena itu, tinjauan sistematis ini akan membahas secara lengkap mengenai peranan MSC pada luka bakar mulai dari mekanisme kerja hingga pengaplikasiannya pada praktik klinis.

\section{METODE}

\section{Strategi Pencarian}

Pencarian literatur dilakukan pada basis data publikasi ilmiah seperti Cochrane library, Pubmed, dan Google scholar dengan menggunakan operator Boolean. Adapun kata kunci yang digunakan adalah [(mesenchymal stem cell OR MSC) AND (burn wound OR burn injury OR thermal injury)]. Rentang studi dibatasi dari tahun 2017 hingga 2021.

\section{Kriteria Eligibilitas}

Untuk kriteria eligibilitas dilakukan penerapan pemilihan studi dengan menggunakan diagram PRISMA. Pada tahap awal dilakukan screening literatur yang diperoleh dari pencarian basis data online sesuai dengan kata kunci yang telah kami tetapkan. Setelah itu kami mengeliminasi temuan dengan judul yang tidak relevan, serta studi-studi yang terduplikasi. Pada tahap kedua dilakukan penilaian abstrak dan literatur naskah lengkap. Pada penilaian tahap kedua ini ditetapkan naskah yang akan diikutkan dalam analisis menggunakan kriteria inklusi dan eksklusi.

Kriteria inklusi yang kami gunakan adalah studi observasional empiris dengan desain berupa studi crosssectional, kontrol-kasus, kohort, uji klinis, maupun laporan kasus mengenai peran mesenchymal stem cell sebagai terapi pada luka bakar termal dan menggunakan sampel hewan coba berupa tikus atau mencit untuk menyeragamkan populasi. Adapun kriteria eksklusi yang digunakan adalah studi bukan berupa uji klinis, studi dengan sampel penelitian berupa luka bakar non-termal, subyek penelitian bukan berupa tikus atau mencit, MSC tidak digunakan sebagai terapi intervensi 
utama serta tidak melibatkan kelompok kontrol dalam studinya. Terdapat reviewer secara independen melakukan telaah studi mulai dari skrining tahap awal pada judul untuk mencegah duplikasi studi hingga evaluasi eligibilitas studi sebelum diikutkan ke dalam tahap sintesis.

\section{Pengumpulan Data}

Literatur yang diidentifikasi kemudian digabung dan dikelola untuk analisis lebih lanjut. Semua literatur yang dipilih dibaca secara menyeluruh dan didalami untuk mendapatkan intisari literatur.

\section{Sintesis Data}

Semua studi yang relevan mengenai peran MSC pada luka bakar dimasukkan dalam sintesis naratif. Sebagai suatu penelitian kualitatif, systematic review ini mencoba menjelaskan temuan peran MSC dalam penatalaksanaan luka bakar. Sintesis naratif dilakukan secara sistematis untuk mendapatkan kesimpulan mengenai peran terapi MSC pada tatalaksana luka bakar mulai dari tinjauan umum hingga mekanisme kerjanya.

\section{HASIL}

Pada tahap awal didapatkan sebanyak 630 studi yanglolos skrining, namun kemudian sebanyak 618 studi tidak memenuhi kriteria inklusi dan eksklusi dengan alasan studi tersebut bukan berupa uji klinis, studi dengan sampel penelitian berupa luka bakar non-termal, subjek penelitian bukan berupa tikus atau mencit, MSC tidak digunakan sebagai terapi intervensi utama serta tidak melibatkan kelompok kontrol dalam studinya sehingga pada tahap akhir didapatkan 12 buah studi yang diikutkan dalam analisis sintesis seperti yang ditunjukkan pada diagram PRISMA (Gambar 1).

\section{Karakteristik Studi}

Pada 12 studi yang diikutsertakan dalam analisis systematic review ini memiliki kualitas studi baik berdasarkan penilaian menggunakan checklist dari The Joanna Briggs Institute. Didapatkan sebanyak 12 uji klinis acak atau randomized controlled trial (RCT). Subyek studi menggunakan tikus dan mencit sebanyak 530 ekor. Studi-studi terpublikasi dalam rentang waktu tahun 2017-2021 dari negara- negara seperti Turki, Iran, Mesir, Amerika Serikat, Kanada, Jepang, Pakistan, dan Korea Selatan. Terapi MSC yang digunakan diisolasi dari sumsum tulang belakang, tali pusat, dan darah tali pusat serta jaringan adiposa. Terdapat satu studi yang mengkombinasikan dengan hidrogel berupa Acgel, dua studi mengkombinasikan dengan gel Aloe vera, dan tiga studi mengkombinasikan MSC dengan platelet rich plasma (PRP). Mode administrasi MSC bervariasi mulai dari topikal, injeksi lokal, subkutan, peritoneal, intra regional, hingga sistemik. Detail karakteristik masing-masing studi dapat dilihat pada Tabel $\mathbf{1}$.

\section{Penilaian kualitas studi}

Penilaian kualitas studi menggunakan checklist dari The Joanna Briggs Institute untuk uji klinis berupa RCT. ${ }^{19}$ Studi dinyatakan berkualitas baik apabila memiliki poin lebih dari atau sama dengan dari setengah nilai maksimum, dan dinyatakan berkualitas rendah apabila memiliki poin kurang dari setengah nilai maksimum. Rentang nilai maksimum adalah 0-13 untuk studi RCT. Penilaian kualitas studi dilakukan oleh dua orang peneliti secara independen untuk mengurangi bias. Dari 12 studi yang dilibatkan didapatkan hasil penilaian baik untuk keseluruhan studi dengan rentang nilai 6-10.

\section{PEMBAHASAN}

Penyembuhan luka bakar merupakan suatu proses fisiologis yang kompleks, meliputi sejumlah mekanisme biologis dan molekuler seperti migrasi dan proliferasi sel, deposisi matriks ekstraseluler, angiogenesis dan proses remodeling. ${ }^{1,4}$ Saat ini terapi regeneratif berupa stem cell tengah dikembangkan untuk mempercepat penyembuhan luka bakar. Berdasarkan stadium perkembangannya, stem cell dapat berasal dari jaringan embrionik maupun

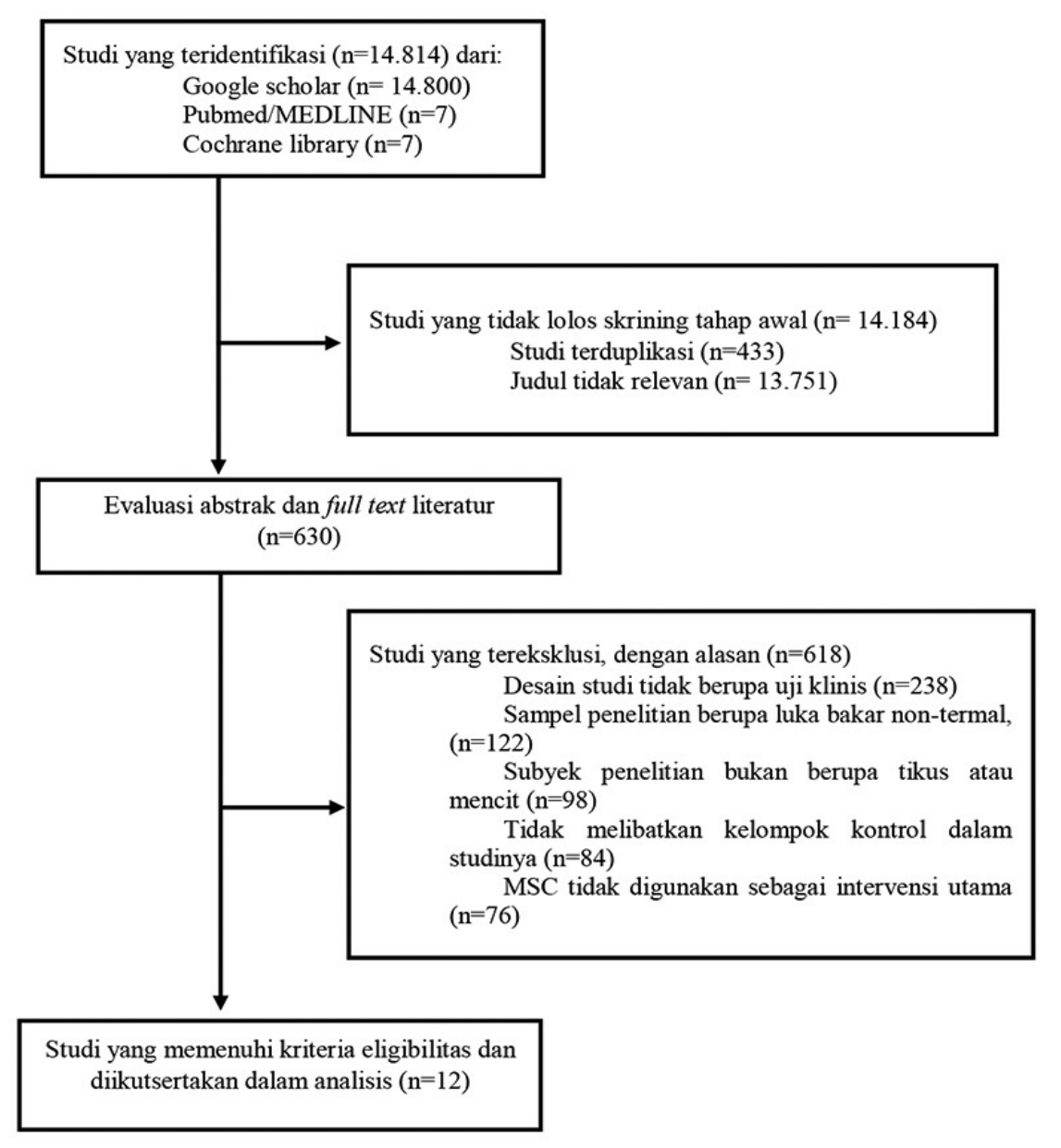

Gambar 1. Diagram PRISMA studi 
dewasa dan mampu berdiferensiasi menjadi berbagai jenis sel. Stem cell terbagi atas totipotent, pluripotent, dan multipotent bergantung pada kemampuan diferensiasinya. Stem cell totipotent dapat berdiferensiasi menjadi sel embrionik dan ekstra-embrionik, sedangkan stem cell pluripotent hanya dapat berdiferensiasi menjadi sel germinal dan somatik saja. Stem cell multipotent dapat berdiferensiasi menjadi jenis sel, jaringan, dan organ yang lebih spesifik. Terdapat sejumlah sumber stem cell yang telah dikembangkan pada terapi regeneratif, khususnya pada penyembuhan luka termasuk luka bakar seperti embryonic stem cells (ESC), umbilical cord stem cells (USC), dan mesenchymal stem cells (MSC)., ${ }^{2,40}$

\section{Mekanisme Terapi MSC dalam Penatalaksanaan Luka Bakar}

Dibandingkan dengan strategi terapi lainnya dalam penatalaksanaan luka bakar, terapi regeneratif menggunakan

Tabel 1. Karakteristik masing-masing studi

\begin{tabular}{|c|c|c|c|c|c|c|}
\hline Studi & Sampel & $\begin{array}{l}\text { Luas dan } \\
\text { derajat luka } \\
\text { bakar }\end{array}$ & Asal MSC & $\begin{array}{c}\text { Jenis } \\
\text { Intervensi }\end{array}$ & Metode & Parameter yang dinilai \\
\hline $\begin{array}{l}\text { Abbas dkk, 2018, } \\
\text { Turki } \\
\text { RCT }\end{array}$ & $\begin{array}{l}50 \text { ekor } \\
\text { tikus wistar }\end{array}$ & $\mathrm{N} / \mathrm{A}$ & $\begin{array}{l}\text { Sumsum tulang } \\
\text { belakang }\end{array}$ & $\begin{array}{l}\text { MSC dalam } \\
\text { PBS }\end{array}$ & $\begin{array}{l}\text { Injeksi } \\
\text { subkutan }\end{array}$ & $\begin{array}{l}\text { Analisa histologi dan } \\
\text { analisa imunohistokimia } \\
\text { untuk melihat kecepatan } \\
\text { peneymbuhan luka. }\end{array}$ \\
\hline $\begin{array}{l}\text { Abdel-Gawad dkk, } \\
\text { 2021, Iran, RCT }\end{array}$ & $\begin{array}{l}90 \text { ekor } \\
\text { tikus }\end{array}$ & $\begin{array}{l}\text { N/A; derajat } \\
\text { III }\end{array}$ & $\begin{array}{l}\text { Sumsum tulang } \\
\text { belakang }\end{array}$ & MSC & $\begin{array}{l}\text { Injeksi } \\
\text { subkutan }\end{array}$ & $\begin{array}{l}\text { Penyembuhan luka melalui } \\
\text { analisa histologi dan } \\
\text { imunihistokimia. }^{8}\end{array}$ \\
\hline $\begin{array}{l}\text { Afzali dkk, 2020, } \\
\text { Iran, RCT }\end{array}$ & $\begin{array}{l}40 \text { ekor } \\
\text { tikus }\end{array}$ & $\begin{array}{l}\text { N/A; derajat } \\
\text { II }\end{array}$ & Darah tali pusat & $\begin{array}{l}\text { MSC + PRP } \\
\text { cryogel }\end{array}$ & Injeksi lokal & $\begin{array}{l}\text { Re-epitelisasi, angiogenesis dan } \\
\text { pembentukan granulasi pada } \\
\text { jaringan. }{ }^{9}\end{array}$ \\
\hline $\begin{array}{l}\text { Alapure dkk, } \\
\text { 2018, USA, RCT }\end{array}$ & 8 ekor tikus & $\begin{array}{l}\text { N/A; derajat } \\
\text { III }\end{array}$ & $\begin{array}{l}\text { Sumsum tulang } \\
\text { belakang }\end{array}$ & $\begin{array}{l}\text { MSC dalam } \\
\text { ACgel }\end{array}$ & Topikal lokal & $\begin{array}{l}\text { Penyembuhan luka, re- } \\
\text { epitelisasi dan granulasi } \\
\text { jaringan, kadar IL-10 dan } \\
\text { TNF- } \alpha^{10}\end{array}$ \\
\hline $\begin{array}{l}\text { Aryan dkk, 2019, } \\
\text { Iran, RCT }\end{array}$ & $\begin{array}{l}32 \text { ekor } \\
\text { tikus }\end{array}$ & $\begin{array}{l}\text { N/A; derajat } \\
\text { II }\end{array}$ & Tali pusat & MSC & $\begin{array}{l}\text { Injeksi } \\
\text { intraperitoneal }\end{array}$ & $\begin{array}{l}\text { Penyembuhan luka dan } \\
\text { neovaskularisasi. }{ }^{11}\end{array}$ \\
\hline $\begin{array}{l}\text { Hosni-Ahmed } \\
\text { dkk, 2017, Mesir, } \\
\text { RCT }\end{array}$ & $\begin{array}{l}72 \text { ekor } \\
\text { tikus wistar }\end{array}$ & $\mathrm{N} / \mathrm{A}$ & $\begin{array}{l}\text { Sumsum tulang } \\
\text { belakang }\end{array}$ & MSC+PRP & $\begin{array}{l}\text { Injeksi } \\
\text { lokal dan } \\
\text { intraregional }\end{array}$ & $\begin{array}{l}\text { Kadar TGF- } \beta \text {, TNF } \alpha \text {, IL-10, } \\
\text { ekspresi gen MMP-1, TIMP-2, } \\
\text { Ang- } 1 \text {, Ang- } 2 .{ }^{12}\end{array}$ \\
\hline $\begin{array}{l}\text { Imbarak dkk, } \\
\text { 2021, Mesir, RCT }\end{array}$ & $\begin{array}{l}60 \text { ekor } \\
\text { tikus }\end{array}$ & $\begin{array}{l}1,5 \mathrm{~cm}^{2} \\
\text { derajat III }\end{array}$ & $\begin{array}{l}\text { Sumsum tulang } \\
\text { belakang }\end{array}$ & MSC+aloe vera & $\begin{array}{l}\text { Injeksi } \\
\text { intradermal }\end{array}$ & $\begin{array}{l}\text { Penyembuhan luka bakar } \\
\text { secara makroskopik. }{ }^{13}\end{array}$ \\
\hline $\begin{array}{l}\text { Kaita dkk, 2019, } \\
\text { Jepang, RCT }\end{array}$ & $\begin{array}{l}18 \text { ekor } \\
\text { mencit }\end{array}$ & $\begin{array}{l}\text { N/A; derajat } \\
\text { III }\end{array}$ & Jaringan adiposa & ADRC & Topikal lokal & $\begin{array}{l}\text { Penyembuhan luka, re- } \\
\text { epitelisasi, neovaskularisasi. }{ }^{14}\end{array}$ \\
\hline $\begin{array}{l}\text { Mahmood dkk, } \\
\text { 2018, Pakistan, } \\
\text { RCT }\end{array}$ & $\begin{array}{l}12 \text { ekor } \\
\text { tikus }\end{array}$ & N/A & Tali pusat & UC-MSC & $\begin{array}{l}\text { Transplantasi } \\
\text { kulit }\end{array}$ & $\begin{array}{l}\text { Arsitektur kulit, penyembuhan } \\
\text { luka dan re-epitelisasi. }{ }^{15}\end{array}$ \\
\hline $\begin{array}{l}\text { Oh dkk, 2018, } \\
\text { Korea Selatan, } \\
\text { RCT }\end{array}$ & $\begin{array}{l}30 \text { ekor } \\
\text { mencit }\end{array}$ & $\begin{array}{l}1,5 \mathrm{~cm}^{2} ; \\
\text { derajat III }\end{array}$ & $\begin{array}{l}\text { Sumsum tulang } \\
\text { belakang }\end{array}$ & MSC & $\begin{array}{l}\text { Injeksi } \\
\text { intravena }\end{array}$ & $\begin{array}{l}\text { Penyembuhan luka dan } \\
\text { neovaskularisasi. }{ }^{16}\end{array}$ \\
\hline $\begin{array}{l}\text { Saad Eldien dkk, } \\
\text { 2019, Mesir, RCT }\end{array}$ & $\begin{array}{l}70 \text { ekor } \\
\text { mencit } \\
\text { dewasa }\end{array}$ & $\begin{array}{l}10 \% \text {; derajat } \\
\text { III }\end{array}$ & $\begin{array}{l}\text { Sumsum tulang } \\
\text { belakang }\end{array}$ & MSC+PRP & $\begin{array}{l}\text { Injeksi } \\
\text { intradermal }\end{array}$ & $\begin{array}{l}\text { Penyembuhan luka, } \\
\text { angiogenesis dan kadar MMP- } \\
13 .{ }^{17}\end{array}$ \\
\hline $\begin{array}{l}\text { Sharifi dkk, 2021, } \\
\text { Iran, RCT }\end{array}$ & $\begin{array}{l}48 \text { tikus } \\
\text { wistar }\end{array}$ & $\begin{array}{l}\text { N/A; derajat } \\
\text { II }\end{array}$ & $\begin{array}{l}\text { Sumsum tulang } \\
\text { belakang }\end{array}$ & $\begin{array}{l}\text { MSC } \\
\text { terenkapsulasi } \\
+ \text { aloe vera }\end{array}$ & Injeksi lokal & $\begin{array}{l}\text { Penyembuhan dan penutupan } \\
\text { luka. }{ }^{18}\end{array}$ \\
\hline
\end{tabular}

Studi diurutkan secara alfabetis. $\mathrm{ADRC}=$ autologous adipose derived regenerative cell; $\mathrm{Ang}=\mathrm{Angiotensin} ; \mathrm{BM}-\mathrm{MSC}=$ bone marrow-mesenchymal stem cell; $\mathrm{CL}$ $\mathrm{MSC}=$ cord lining-mesenchymal stem cell; $\mathrm{IL}=$ Interleukin; $\mathrm{MMP}=$ matrix metalloproteinase; $\mathrm{PRP}=$ platelet rich plasma; $\mathrm{RCT}=$ randomized control trial; $\mathrm{TEWL}=$ transepidermal water loss; TGF- $\beta 1=$ transforming growth factor $-\beta 1$; TNA- $\alpha=$ Tumor Necrosis Factor alpha; TIMP-2=Tissue Inhibitor Metalloproteinase-2; UC$\mathrm{MSC}=$ umbilical cord-mesenchymal stem cell. 


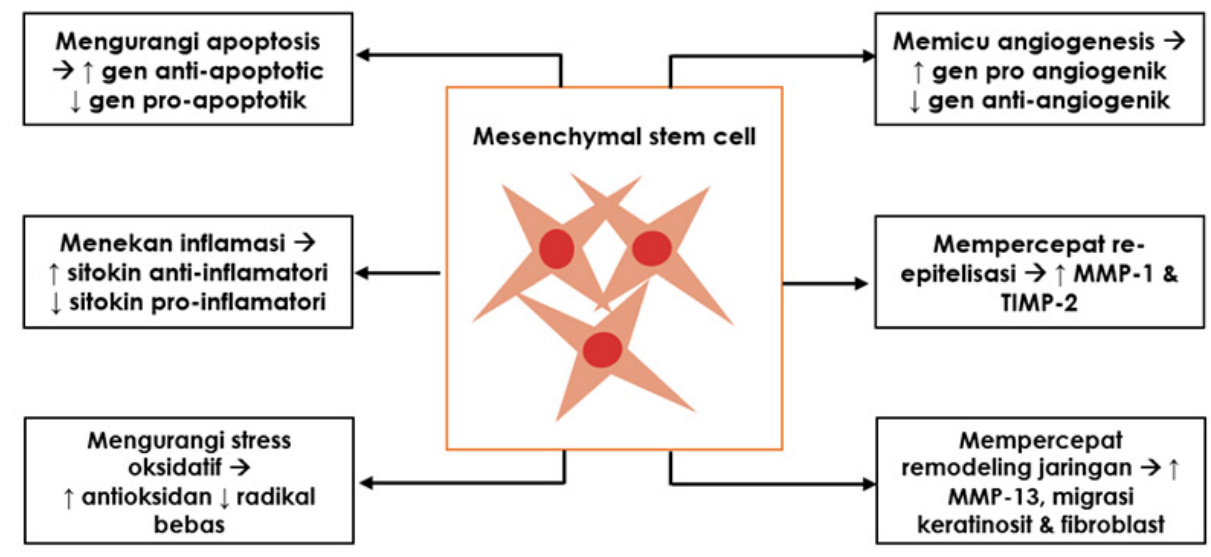

Gambar 2. Mekanisme mesenchymal stem cell (MSC) dalam penyembuhan luka bakar

MSC lebih superior dari berbagai aspek. Dari hasil analisis sintesis sejumlah literatur didapatkan bahwa MSC membantu mempercepat penyembuhan luka pada kasus luka bakar melalui sejumlah mekanisme seperti mengurangi apoptosis, menekan proses inflamasi dan stres oksidatif, serta berperan dalam proses angiogenesis. ${ }^{7-10}$ Skema mekanisme MSC dalam penyembuhan luka bakar ditunjukkan oleh Gambar 2.

\section{Mengurangi apoptosis}

Hasil analisa imunohistokimia oleh Abbas dkk. menemukan transplantasi sel punca mengurangi terjadinya apoptosis sel pada zona stasis melalui perbaikan keseimbangan protein anti-apoptosis dan pro-apoptosis. ${ }^{7}$ Evaluasi genetik menunjukkan sel punca mesenkimal menekan ekspresi gen Bax yang bersifat pro-apoptosis, di sisi lain meningkatkan ekspresi gen anti-apoptosis Bcl2. ${ }^{7}$ Studi Mahmood dkk. juga mengamati lebih banyak sel apoptotik pada kelompok kontrol dibandingkan kelompok intervensi yang ditransplantasikan MSC. Ekspresi gen apoptotik yakni BAX dan FADD ditemukan berkurang pada kelompok intervensi. ${ }^{15}$

\section{Menekan inflamasi}

Proses inflamasi merupakan komponen penting dalam proses penyembuhan luka, dimana proses inflamasi yang berkepanjangan dapat menghambat waktu dan kualitas penyembuhan luka. Jumlah leukosit yang berlebihan, khususnya neutrofil, diasumsikan berhubungan dengan perburukan kondisi luka akibat produksi mediator inflamasi berlebih, menghambat mikrovaskular dan dihasilkannya radikal reaktif. Transplantasi sel punca mesenkimal mampu menurunkan infiltrasi neutrofil ke zona stasis, ditunjukkan oleh berkurangnya jumlah neutrofil absolut dan aktivitas myeloperoksidase. Penekanan respon inflamasi oleh sel punca mesenkimal turut berkontribusi dalam efek protektif pada luka bakar dengan mengurangi sitotoksisitas, mengatasi stres oksidatif dan mempertahankan patensi vaskuler. Inflamasi merupakan suatu proses yang dipengaruhi keseimbangan antara faktor pro-inflamasi dan anti-inflamasi. Pada kondisi luka bakar termal, ekspresi sitokin pro-inflamasi seperti TNF- $a$, IL$1 \beta$, dan IL-6 meningkat secara signifikan pada zona stasis dan juga meningkatnya IL-10 sebagai sitokin anti-inflamasi. Transplantasi sel punca mesenkimal terbukti dapat menurunkan ekspresi TNF- $\alpha$, IL- $1 \beta$, dan IL-6 sembari tetap meningkatkan ekspresi IL-10. Terapi sel punca mesenkimal mengurangi progresi luka bakar melalui efek imunomodulator yang meliputi berkurangnya infiltrasi neutrofil, mengurangi ekspresi sitokin pro-inflamasi, dan meningkatkan ekspresi anti-inflamasi pada jaringan lokal. ${ }^{7}$ Temuan lainnya oleh Hosni-Ahmed dkk juga menunjukkan berkurangnya kadar sitokin pro-inflamasi TNF- $\alpha$ dan meningkatkan sitokin anti-inflamasi IL-10 pada kelompok intervensi. ${ }^{12}$

\section{Mengurangi stres oksidatif}

Pada luka bakar juga terjadi stres oksidatif yang memperparah kerusakan jaringan pada zona stasis. Pada luka bakar akut, terjadi stres oksidatif yang menyebabkan kerusakan jaringan dengan peroksidasi membran lipid, degradasi protein, dan kerusakan asam nukleat pada sel. Penelitian oleh Abbas dkk. menunjukkan terjadinya peningkatan stres oksidatif pasca luka bakar, dibuktikan dengan peningkatan kadar malondialdehyde. Pasca dilakukannya transplantasi sel punca mesenkimal, stres oksidatif berkurang signifikan dimana hal ini dapat dikaitkan dengan berkurangnya respon inflamasi. Kondisi luka bakar juga meningkatkan produksi radikal bebas yang mengganggu mekanisme pertahanan antioksidan, sehingga menyebabkan jaringan yang mengalami luka bakar lebih mudah mengalami kerusakan oksidatif. Pasca terapi sel punca, ditemukan adanya pengurangan signifikan pada ekspresi dan aktivitas antioksidan superoxide dismutase (SOD) ${ }^{7}$

\section{Membantu angiogenesis}

Faktor kunci lain dalam pemburukan kondisi luka bakar adalah terganggunya aliran darah pada zona stasis. Selain diakibatkan oleh apoptosis dan nekrosis, gangguan aliran darah pada bagian dermis dan vaskuler kulit juga turut mempengaruhi viabilitas keratinosit pada struktur adneksa kulit sehingga menghambat penyembuhan luka. Terganggunya mikrosirkulasi pada jaringan yang rusak akibat luka bakar tersebut terjadi akibat kombinasi sejumlah faktor seperti vasokonstriksi, edema jaringan, pembentukan mikro trombus, sumbatan neutrofil, dan kerusakan endotel yang diinduksi radikal bebas. Studi oleh Abbas dkk. menunjukkan terapi MSC mampu memperbaiki densitas vaskuler, dibuktikan melalui evaluasi skintigrafiyang mengkonfirmasi perbaikan dan restorasi suplai aliran darah. Selain itu sel punca mesenkimal juga menginduksi terjadinya neo-angiogenesis dan melindungi sel endotel dari proses apoptosis. Selain itu pada kelompok uji klinis yang diberikan terapi sel punca, ditemukan ekspresi VEGF, PDGF, FGF, dan TGF yang lebih tinggi, mengindikasikan bahwa faktorfaktor tersebut turut berkontribusi pada kemampuan vaskulotropik sel punca mesenkimal. $^{7}$ 
Temuan tersebut didukung oleh hasil penelitian Afzali dkk., dimana terapi MSC dari tali pusat meningkatkan kadar VEGF sehingga memicu terjadinya angiogenesis. ${ }^{9}$ Angiogenesis merupakan tahap awal dari terjadinya penyembuhan luka dan diatur oleh keseimbangan antara faktor pro-angiogenik (Ang-1 dan Ang2) serta faktor anti-angiogenik (IL-2 dan TIMP). Studi tersebut juga menemukan MSC meningkatkan ekspresi Ang-1 dan gen VEGF pada kelompok intervensi, dimana kadarnya ditemukan meningkat pada hari ke-21. ${ }^{9}$ Studi Alapure dkk. juga menunjukkan pasca terapi MSC terjadi angiogenesis lebih cepat ditunjukkan dengan meningkatnya vaskularitas pada area luka dibandingkan kelompok kontrol. ${ }^{10}$

Dari hasil analisa Western Blot dari penelitian Oh dkk. ditemukan peningkatan kadar TGF- $\beta 1$ and VEGF pasca adminitrasi MSC. ${ }^{16}$ TGF- $\beta 1$ berfungsi meningkatkan vaskularisasi melalui berbagai reseptor dan persinyalan intraseluler. VEGF juga mempercepat penyembuhan luka melalui proses neovaskularisasi, deposisi kolagen, dan reepitelisasi. Studi oleh Saad Eldien dkk. ${ }^{17}$ juga mendapatkan hasil peningkatan penanda angiogenik seperti Ang-2 dan VEGF. Konsentrasi Ang-2 yang tinggi meningkatkan keberlangsungan hidup sel endotel serta migrasi dari darah menuju jaringan ikat dan pembentukan pembuluh darah kapiler yang baru. Pembuluh kapiler baru bersatu membentuk jaringan vaskuler sehingga aliran darah dapat ditingkatkan. ${ }^{16}$

\section{Mempercepat proses re-epitelisasi}

Proses re-epitelisasi dan granulasi jaringan merupakan proses krusial pada fase penyembuhan luka akibat luka bakar. Uji klinis acakoleh Alapure dkk. menggunakan MSC dalam kapsul ACgel menemukan proses re-epitelisasi yang signfikan lebih tinggi disbanding kelompok kontrol dintujukkan oleh analisa menggunakan pewarnaan Hematoxylin \& Eosin (H\&E).$^{10}$ Selain itu pada area luka yang diterapi dengan MSC juga menghasilkan granulasi jaringan yang lebih luas dibandingkan kontrol. ${ }^{10}$ Studi lainnya oleh Saad-Eldien $\mathrm{dkk}$. teramati adanya proses re-epitelisasi penuh pada kelompok intervensi. ${ }^{17}$ MMP dan TIMP memainkan peran penting pada proses re-epitelisasi dimana keduanya mengatur degradasi dan deposisi matriks esktraseluler. Studi Hosni-Ahmed dkk. menemukan peningkatan ekspresi gen MMP-1 dan TIMP-2 pasca administrasi MSC. ${ }^{12,17}$ Studi oleh Mahmood dkk. mendapatkan hasil bahwa proses re-epitelisasi lebih tinggi kelompok kontrol yang dilakukan transplantasi MSC dibandingkan kelompok kontrol. Penyembuhan luka juga lebih cepat, yakni mencapai $78 \%$ pada hari ke-10 dibandingkan kelompok kontrol yang hanya $31,8 \%$. Penyembuhan total pada kelompok intervensi terjadi pada hari ke20 , lebih cepat dibandingkan kelompok kontrol yang sembuh total pada hari ke$27 .^{15}$

\section{Mempercepat proses remodelling jaringan}

Studi oleh Saad Eldien dkk. menemukan bahwa kombinasi MSC dan PRP dapat mempercepat proses remodelling jaringan ditandai dengan peningkatan ekspresi MMP-13. ${ }^{17}$ MMP-13 diketahui memiliki efek potensial untuk membelah serat kolagen dan komponen matriks ekstraseluler lainnya bersama dengan TGF- $\beta$. MMP-13 memainkan peran penting dalam proses remodelling jaringan dan perbaikan pada area luka tanpa membentuk jaringan parut. ${ }^{17}$

Studi lainnya yakni uji klinis acak oleh Kaita dkk. mengevaluasi regenerasi kulit pasca administrasi MSC yang berasal dari jaringan adiposa dengan membandingkan ketebalan kulit. ${ }^{14}$ Terdapat perbedaan signifikan antara kelompok intervensi dengan kelompok kontrol yang hanya diberikan PBS. Dari penelitian tersebut juga ditemukan bahwa MSC yang berasal dari jaringan adiposa menstimulasi proliferasi dan migrasi keratinosit dan fibroblas secara in vitro serta mengurangi area luka dengan meregenerasi lapisan dermis dan mempercepat proses vaskularisasi. $^{14}$

Pada proses penyembuhan luka termasuk akibat luka bakar terjadi sejumlah proses kompleks yang meliputi beberapa fase yakni, hemostasis, inflamasi, proliferasi, dan remodelling. Uji klinis oleh Hosni-Ahmed dkk. menunjukkan bahwa terapi MSC pada luka bakar berperan dalam mengurangi luas luka bakar melalui hasil analisis menggunakan pewarnaan
H\&E. Pada kulit yang mengalami luka bakar ditemukan perubahan patologis berupa hilangnya jaringan pada lapisan epidermis dan nekrosis koagulasi pada lapisan dermis disertai adanya sel inflamasi dan kolagen terkoagulasi. Pasca administrasi MSC yang diisolasi dari sumsum tulang belakang terjadi epitelisasi lengkap dan peningkatan jumlah kapiler pada lapisan dermal serta berkurangnya jumlah sel inflamasi pada hari ke-20 pasca luka bakar. Temuan tersebut mengindikasikan transplantasi MSC dapat mempercepat proses penyembuhan. Penelitian tersebut juga menunjukkan bahwa kombinasi MSC dengan platelet rich plasma (PRP) memberikan hasil penyembuhan luka paling maksimal pada hari ke-20 pascaluka bakar terjadi, terbukti dengan adanya regenerasi komplit pada lapisan epidermis, dermis, hipodermis, serat otot, pembentukan pembuluh darah baru, dan folikel rambut..$^{15}$ Studi RCT oleh Aryan dkk. menyimpulkan bahwa terapi MSC dari tali pusat manusia mempercepat penyembuhan luka dengan meningkatkan proliferasi sel, meningkatkan sintesis dan komposisi kolagen, serta menginduksi angiogenesis pada area luka bakar. ${ }^{11}$

Studi oleh Abdel-Gawad dkk. meneliti sejumlah indikator yang menunjukkan percepatan penyembuhan luka berupa proses re-epitelisasi dan ketebalan epidermis pasca administrasi MSC dari sumsum tulang belakang. ${ }^{8}$ Ditemukan bahwa pasca administrasi, MSC akan bermigrasi ke area luka dan berinteraksi dengan sel epitel dan memicu regenerasi kulit. Terapi MSC juga terbukti menurunkan risiko terbentuknya kontraktur pada area luka bakar karena dapat merestorasi struktur kulit melalui proses inhibisi proses inflamasi, meningkatkan angiogenesis, stimulasi migrasi fibroblas dan produksi kolagen melalui mekanisme parakrin. ${ }^{8}$ Studi oleh Imbarak dkk. juga mendukung temuan tersebut, pada kelompok yang diinjeksi MSC menunjukkan peningkatan regenerasi epidermis dan peningkatan densitas serat kolagen pada hari 14 intervensi dibandingkan kelompok kontrol. ${ }^{13}$ Mekanisme penyembuhan luka tersebut dipengaruhi oleh persinyalan parakrin yang memicu produksi faktor pertumbuhan seperti EGF, 
VEGF, keratinocyte growth factor, dan fibroblast growth factor. Studi lainnya yang juga mendukung temuan tersebut adalah Sharifi dkk. yang menemukan peningkatan ekspresi VEGF, kolagen tipe 1 , dan kolagen tipe 3 yang signifikan pada kelompok intervensi. ${ }^{18}$ Studi tersebut juga menunjukkan efek sinergis antara MSC dan gel Aloe vera dalam mempercepat proses penyembuhan luka bakar dibuktikan dengan menutupnya luka yang jauh lebih cepat dibandingkan kelompok kontrol. ${ }^{13}$

Keseluruhan studi yang diikutkan dalam analisis sintesis telaah pustaka sistematis ini menunjukkan bahwa terapi MSC berperan dalam mempercepat proses penyembuhan luka bakar dan mengurangi risiko terjadinya jaringan parut. Selain itu dari keseluruhan studi tidak ada yang melaporkan efek samping yang bermakna seperti adanya aktivitas neoplastik maupun respon imun yang berlebihan. ${ }^{10,11,17}$ Temuan-temuan tersebut menjadikan terapi MSC sebagai terapi regeneratif yang potensial untuk dikembangkan dan diaplikasikan dalam penatalaksanaan luka bakar. Adapun keterbatasan dari tinjauan sistematis ini adalah keterbatasan jumlah sampel penelitian serta belum melibatkan studi yang menggunakan pasien manusia sebagai subyek penelitiannya.

\section{SIMPULAN}

Mesenchymal stem cell (MSC) merupakan sel punca dewasa multipotent yang dapat diisolasi dari berbagai bagian tubuh manusia seperti sumsum tulang belakang, darah, dan tali pusat serta jaringan adiposa. Studi menunjukkan MSC berperan dalam penyembuhan luka bakar melalui mekanisme menekan apoptosis, mengurangi proses inflamasi dan stress oksidatif pada luka bakar, memicu terjadinya angiogenesis, mempercepat proses re-epitelisasi, dan remodelling jaringan. MSC potensial untuk digunakan sebagai terapi regeneratif dalam penatalaksanaan luka bakar.

\section{KONFLIK KEPENTINGAN}

Penulis menyatakan tidak terdapat konflik kepentingan terkait publikasi dari artikel ini.

\section{PENDANAAN}

Penelitian ini tidak mendapat dana hibah dari pemerintah ataupun lembaga swasta lainnya.

\section{KONTRIBUSI PENULIS}

Penulis berkontribusi terhadap penelitian ini baik dari perencanaan hingga interpretasi dan penyusunan naskah publikasi.

\section{DAFTAR PUSTAKA}

1. Garcia-Espinoza JA, Aguilar-Aragon VB, Ortiz-Villalobos EH, Garcia-Manzano RA, Antonio BA. Burns: definition, classification, pathophysiology, and initial approach. Gen Med. 2017;5(5): 1-5. doi:10.4172/23275146.1000298.

2. Yi H, Wang Y, Yang Z, Xie Z. Efficacy assessment of mesenchymal stem cell transplantation for burn wounds in animals: a systematic review. Stem Cell Res Ther. 2020;11(1):372. Published 2020 Aug 28. doi:10.1186/s13287-020-01879-1.

3. Kementerian Kesehatan RI. Pedoman Nasional Pelayanan Kedokteran Tatalaksana Luka Bakar. 2019. p5-6.

4. Abdul Kareem N, Aijaz A, Jeschke MG. Stem Cell Therapy for Burns: Story so Far. Biologics. 2021;15:379-397. Published 2021 Aug 31. doi:10.2147/BTT.S259124.

5. Li Y, Xia WD, Van der Merwe L, Dai WT, Lin C. Efficacy of stem cell therapy for burn wounds: a systematic review and metaanalysis of preclinical studies. Stem Cell Res Ther. 2020;11(1):322. Published 2020 Jul 29. doi:10.1186/s13287-020-01839-9.

6. Ahmadi AR, Chicco M, Huang J, et al. Stem cells in burn wound healing: A systematic review of the literature. Burns. 2019;45(5):10141023. doi:10.1016/j.burns.2018.10.017.

7. Abbas OL, Özatik O, Gönen ZB, et al. Prevention of Burn Wound Progression by Mesenchymal Stem Cell Transplantation: Deeper Insights Into Underlying Mechanisms. Ann Plast Surg. 2018;81(6):715-724. doi:10.1097/ SAP.0000000000001620.

8. Abdel-Gawad DRI, Moselhy WA, Ahmed RR, et al. Therapeutic effect of mesenchymal stem cells on histopathological, immunohistochemical, and molecular analysis in second-grade burn model. Stem Cell Res Ther. 2021;12(1):308. Published 2021 May 29. doi:10.1186/s13287021-02365-y.

9. Afzali, Lotfollah \& Mirahmadi-Babaheydari, Fatemeh \& Shojaei-Ghahrizjani, Fereshteh \& Rahmati, Shima \& Shahmoradi, Babak \& Banitalebi-Dehkordi, Mehdi. The Effect of Encapsulated Umbilical Cord-derived Mesenchymal Stem Cells in PRPCryogel on Regeneration of Grade-II Burn Wounds. Regenerative Engineering and Translational Medicine. 2020. p1-11. doi:10.1007/s40883020-00188-6.
10. Alapure BV, Lu Y, He M, et al. Accelerate Healing of Severe Burn Wounds by Mouse Bone Marrow Mesenchymal Stem Cell-Seeded Biodegradable Hydrogel Scaffold Synthesized from Arginine-Based Poly(ester amide) and Chitosan. Stem Cells Dev. 2018;27(23):16051620. doi:10.1089/scd.2018.0106.

11. Aryan A, Bayat M, Bonakdar S, et al. Human Bone Marrow Mesenchymal Stem Cell Conditioned Medium Promotes Wound Healing in Deep Second-Degree Burns in Male Rats. Cells Tissues Organs. 2018;206(6):317329. doi:10.1159/000501651.

12. Hosni Ahmed H, Rashed LA, Mahfouz S, et al. Can mesenchymal stem cells pretreated with platelet-rich plasma modulate tissue remodeling in a rat with burned skin?. Biochem Cell Biol. 2017;95(5):537-548. doi:10.1139/bcb2016-0224.

13. Imbarak N, Abdel-Aziz HI, Farghaly LM, Hosny S. Effect of mesenchymal stem cells versus aloe vera on healing of deep second-degree burn. Stem Cell Investig. 2021;8:12. Published 2021 Jun 15. doi:10.21037/sci-2020-030.

14. Kaita Y, Tarui T, Yoshino H, et al. Sufficient therapeutic effect of cryopreserved frozen adipose-derived regenerative cells on burn wounds. Regen Ther. 2019;10:92-103. Published 2019 Feb 1. doi:10.1016/j.reth.2019.01.001.

15. Mahmood R, Mehmood A, Choudhery MS, Awan SJ, Khan SN, Riazuddin S. Human neonatal stem cell-derived skin substitute improves healing of severe burn wounds in a rat model. Cell Biol Int. 2019;43(2):147-157. doi:10.1002/cbin.11072.

16. Oh EJ, Lee HW, Kalimuthu S, et al. In vivo migration of mesenchymal stem cells to burn injury sites and their therapeutic effects in a living mouse model. J Control Release. 2018;279:79-88. doi:10.1016/j. jconrel.2018.04.020.

17. Saad Eldien HM, Mostafa NA, Abd ElTawab O, Hassan H, Abd Elhamid TH, Abd Elhaliem NG, Kamal A. Effect of hematopoietic stem cells and platelet-rich plasma on the healing of experimental skin burned tissues: A comparative study in adult male mice. Egyptian Journal of Histology. 2019; 42(3): 740-754. doi: 10.21608/EJH.2019.8023.1083.

18. Sharifi E, Chehelgerdi M, FatahianKelishadrokhi A, Yazdani-Nafchi F, AshrafiDehkordi K. Comparison of therapeutic effects of encapsulated Mesenchymal stem cells in Aloe vera gel and Chitosan-based gel in healing of grade-II burn injuries. Regen Ther. 2021;18:3037. Published 2021 Mar 21. doi:10.1016/j. reth.2021.02.007.

19. The Joanna Briggs Institute. Reviewer's Manual. Australia: The Joanna Briggs Institute; 2014.

20. Mahmoudian-Sani MR, Rafeei F, Amini R, Saidijam M. The effect of mesenchymal stem cells combined with platelet-rich plasma on skin wound healing. J Cosmet Dermatol. 2018;17(5):650-659. doi:10.1111/jocd.12512.

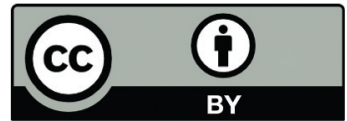

This work is licensed under a Creative Commons Attribution 